\title{
Phytochemical study of Mikania pseudohoffmanianna G. M. Barroso ex W. C. Holmes
}

\author{
Janaina Moreira de Souza', Silvia Helena Taleb-Contini², Dionéia Camilo Rodrigues de Oliveira ${ }^{1 *}$ \\ 1Departamento de Física e Química, Faculdade de Ciências Farmacêuticas de Ribeirão Preto, Universidade de \\ São Paulo, ${ }^{2}$ Departamento de Química, Faculdade de Filosofia Ciências e Letras de Ribeirão Preto, Universidade \\ de São Paulo
}

*Correspondence:

D. C. R. Oliveira

Departamento de Física e Química

Faculdade de Ciências Farmacêuticas

de Ribeirão Preto, USP

Via do Café, $\mathrm{s} / \mathrm{n}$

14040-903-Ribeirão Preto, SP - Brasil

E-mail:drolivei@fcfrp.usp.br
This work describes the fractionation of methanol and dichloromethane extracts of aerial parts from the Mikania pseudohoffmanniana G. M. Barroso ex W. C. Holmes. The phytochemical study of extracts led to isolation and the identification of 16 known compounds, including: steroids: campesterol, stigmasterol and $\beta$-sitosterol, diterpenes: ent15 $\beta$-E-cinnamoyloxy-kaur-16-en-19-oic acid, ent-15 $\beta$-Zcinnamoyloxy-kaur-16-en-19-oic acid and ent-kaur-16-en-19-oic acid, triterpenes: $\alpha$-amyrin, $\beta$-amyrin, $\alpha$-amyrin acetate, $\beta$-amyrin acetate, lupeol, lupeol acetate and friedelin, coumarin: scopoletin, flavonoid: quercetin and caffeoyl quinic acid derivative: 4,5-di-O-[E]-caffeoyl quinic acid.
Uniterms

- Mikania

pseudohoffmanianna

- Asteraceae

- Terpenoids

- Flavonoids

- Quinic acid derivative

\section{INTRODUCTION}

The genus Mikania (family Asteraceae, tribe Eupatoriae, subtribe Mikaniinae) is widespread in Brazil, 150 of its 300 species occurring in this country (King, Robinson, 1987). Some species of the genus known as guaco are traditional medicine used against a variety of diseases (Holetz et al., 2002).

Mikania pseudohoffmanniana G. M. Barroso ex W. Holmes is an endemic vine found in Brazil in Minas Gerais, Paraná and São Paulo. A great variety of constituents, the taxonomic complexity and biological applications justify the phytochemical study of species in the family (King; Robinson, 1987). We have been investigating the chemical composition of Brazilian guaco belonging to the genus Mikania. As part of this work we report here the isolation and structural determination of some constituents from the aerial parts of Mikania pseudohoffmanniana.

\section{MATERIAL AND METHODS}

\section{General}

The IR spectra were recorded on a Nicolet Protégé460 spectrophotometer in the $4000-600 \mathrm{~cm}^{-1}$ range in the form of KBr pellets. ${ }^{1} \mathrm{H}\left(300\right.$ and $400 \mathrm{MHz}$ ) and ${ }^{13} \mathrm{C}$ NMR (75 and $100 \mathrm{MHz}$ ) spectra were obtained on a Bruker DPX 300 or 400 in $\mathrm{CDCl}_{3}$, Methanol-d or DMSO-d $_{6}$ with TMS as internal standard. ESI-MS and ESI-MS/MS spectra were obtained on a Micromass Quattro LC spectrometer.

\section{GC analyses}

HRGC analyses were performed on a HewlettPackard 5890 model Serie-II gas chromatograph equipped with a $30 \mathrm{~m} \times 0,25 \mathrm{~mm}$ d. i., column coated $(0,25 \mu \mathrm{m}$ film thickness $)$ with cross-linked poly- 
methyseloxone (HP-1) and $30 \mathrm{~m} \times 0,25 \mathrm{~mm}$ d. i., column coated $(0,25 \mu \mathrm{m}$ film thickness) with cross-linked $50 \%$ phenyl-methyseloxone (HP-50). Samples were introduced using the split mode (Split ratio $1: 60$ ) a $260^{\circ} \mathrm{C}$. Hydrogen was used as carrier gas at an average linear velocity $42 \mathrm{~cm} / \mathrm{s}$ at $250{ }^{\circ} \mathrm{C}$. Temperature FID was $300^{\circ} \mathrm{C}$. For HP-50 the column temperature was $280{ }^{\circ} \mathrm{C}$ (isotherm) and for HP-1 the column temperature program was $250{ }^{\circ} \mathrm{C}$ held for $12 \mathrm{~min}$, increased at $6{ }^{\circ} \mathrm{C} / \mathrm{min}$ to $280{ }^{\circ} \mathrm{C}$, and held this temperature for $20 \mathrm{~min}$. The inject volume was $1 \mu \mathrm{L}$. Data were processed on a HewlettPackard 3395 model. The certified standard of sterols (stigmasterol, campesterol an $\beta$-sitosterol) employed in HRGC analysis were purchased from Supelco Inc., while the triterpenes $(\alpha$-amyrin, $\beta$-amyrin, $\alpha$-amyrin acetate, $\beta$-amyrin acetate, lupeol, lupeol acetate and friedelin) used as standards were isolated from different plant material in our laboratory and identified by spectral data of ${ }^{1} \mathrm{H}$ and ${ }^{13} \mathrm{C}$ NMR measurements.

\section{Plant Material}

Mikania pseudohoffmanniana G.M. Barroso ex W.C. Holmes was collected at Campos do Jordão-SP, Brazil, in May 2000, and was identified by Prof. Dr. Roberto Lourenço Esteves (Departamento de Biologia Animal e Vegetal da Universidade Federal do Rio de Janeiro). A voucher sample (NPL-269 and NPL-276) was deposited in the herbarium of the Departament of Biology, FFCLRP-USP and was used for the authentication of the species.

\section{Extraction and fractionation}

Dried and powdered whole M. pseudohoffmanniana plants $(1.3 \mathrm{~kg})$ were extracted exhaustively at room temperature with dichloromethane and methanol in successive phases. Solvents were evaporated under reduced pressure and furnished $22.0 \mathrm{~g}$ and $40.0 \mathrm{~g}$, respectively. The dichloromethane extract was chromatographed over Si gel H eluting with hexane, and gradually increasing the polarity with EtOAc and $\mathrm{MeOH}$. Thirteen fractions were collected and monitored by TLC. Fractions $1(2.62 \mathrm{~g})$ and $2(7.59 \mathrm{~g})$ were analyzed by GC and it was identified a mixture of stigmasterol, $\alpha$-amyrin and its acetate, $\beta$-amyrin acetate, lupeol and its acetate fraction 1 furnished $\beta$-sitosterol and fraction 2 furnished $\beta$-amyrin and friedelin. The fraction $3(5.15 \mathrm{~g})$ was chromatographed over Si gel 60 eluting with hexane, and gradually increasing the polarity with EtOAc and $\mathrm{MeOH}$. Fourteen fractions were collected and monitored by TLC. The fraction $3(35.0 \mathrm{mg})$ was subjected to prep. TCL (silica-gel) eluted in dichloromethane:acetone (19:1) gave a mixture of $3.0 \mathrm{mg}$ of ent-15 $\beta$-E-cinnamoyloxy-kaur-16en-19-oic and ent-15 $\beta$-Z-cinnamoyloxy-kaur-16-en-19oic acids. The fraction $5(54.0 \mathrm{mg})$ was submitted to prep. TCL (silica gel) eluted in dichloromethane:acetone (7:3) gave ent-kaur-16-en-19-oic acid ( $2 \mathrm{mg})$. The crude methanolic extract underwent a partition by utilizing $\mathrm{MeOH}: \mathrm{H}_{2} \mathrm{O}$ (9:1), hexane, chloroform and buthanol. That procedure yields a precipitate $(1.4 \mathrm{~g})$ and the hexane $(0.4$ $\mathrm{g}), \mathrm{CHCl}_{3}(5.8 \mathrm{~g})$ and buthanolic $(10.5 \mathrm{~g})$ fractions. The precipitate and hexane fraction were analyzed by GC and a mixture of stigmasterol, $\alpha$-amyrin and its acetate, $\beta$ amyrin and its acetate, lupeol and its acetate were identified in both. The hexane fraction contained campesterol, friedelin and ent-kaur-16-en-19-oic acid. The chloroformic fraction was chromatographed over $\mathrm{Si}$ gel 60 eluting with hexane, and gradually increasing the polarity with EtOAc and $\mathrm{MeOH}$. Thirteen fractions were collected and monitored by TLC. The fraction 7 (76.0 $\mathrm{mg}$ ) was subject to prep. TCL (silica gel) eluted in dichloromethane:acetone (8:2) gave scopoletin $(3.0 \mathrm{mg})$. A part of the buthanolic fraction $(3.5 \mathrm{~g})$ from the crude methanolic extract was chromatographed on a Sephadex LH - 20 column using methanol as eluent, and 10 fractions were collected. Fraction 6 gave 4,5-di- $O$ - $[E]-$ caffeoyl quinic acid $(7.0 \mathrm{mg})$ and fraction 14 gave of quercetin $(8.0 \mathrm{mg})$.

\section{RESULTS AND DISCUSSION}

Phytochemical study of Mikania pseudohoffmanniana led to possible the identification of 16 compounds. Triterpenes ( $\alpha$-amyrin, $\beta$-amyrin, $\alpha$-amyrin acetate, $\beta$-amyrin acetate, lupeol, lupeol acetate and friedelin) and steroids (campesterol, stigmasterol and bð-sitosterol) are all described in literature and were identified by ${ }^{1} \mathrm{H}$ NMR data and HRGC. Identification of the steroids and triterpenes was carried out by comparison of relative retention times with those of references compounds. Acid diterpenes of kaurenes bulk (ent-15 $\beta$-E-cinnamoyloxy-kaur-16-en-19-oic, ent$15 \beta$-Z-cinnamoyloxy-kaur-16-en-19-oic and ent-kaur16-en-19-oic acids) were identified by IR, ${ }^{1} \mathrm{H}$ and ${ }^{13} \mathrm{C}$ NMR spectra and the data were compared with thoses reported in the literature (Silverstein et al., 1994; Vichnewskil et al., 1977; Reed et al., 1993; Velandia et al., 1998; Ohno et al., 1979; Yamasaki et al., 1976). Scopoletin coumarin was identified by IR, ${ }^{1} \mathrm{H}$ and ${ }^{13} \mathrm{C}$ NMR spectra and mass espectometry and the data were compared with the ones found in literature (Dean, et al., 1967; Nascimento, Oliveira, 2001). The 
derivative of caffeoyl quinic acid: 4,5-di- $O$-[E]-caffeoyl quinic acid and flavonoid: quercetin were identified by IR, ${ }^{1} \mathrm{H}$ and ${ }^{13} \mathrm{C}$ NMR spectra and mass espectometry and the data were compared with thoses reported in the literature (Pauli et al., 1998; Merfort, 1992; SánchezRabaneda, et al., 2003; Santos, 2004; Harborne, et al., 1986; Fabre, et al.; 2001; Erlend, Dag, 2002).

These classes of substances identified and isolated from the species Mikania pseudohoffmanniana fit into the profile displayed by the Mikania genus. All these substances have been described in the literature and most are widely distributed in the Asteraceae family and they also present studies in relation to some biologic activities such as antimicrobial and trypanocidal ones (Alves, et al., 1995; Holetz, et al., 2002). The bronchodilatador activity of Mikania species is related to the presence of coumarin and the antimicrobial activity is attributed to the presence of diterpene of the kaurenes type (Moura, et al., 2001; Lentz, et al., 1998).

As to chemosystematics the chemical profile of Mikania pseudohoffmanniana presented in this work is similar to that of other Brazilian Mikania species. Since this is the first study of this plant that has ever been carried out this is a valuable contribution to the knowledge of its chemical profile.

\section{ACKNOWLEDGEMENTS}

The authors are grateful to Fundação de Amparo à Pesquisa do Estado de São Paulo (FAPESP), CAPES and $\mathrm{CNPq}$ for financial support and FAPESP, for a graduate fellowship to J.M.S.; to Prof. R.L. Esteves for plant identification.

\section{RESUMO}

\section{Estudo fitoquímico de Mikania pseudohoffmanianna G. M. Barroso ex W. C. Holmes}

O fracionamento dos extratos diclorometânico e metanólico das partes aéreas de Mikania pseudohoffmanniana G. M. Barroso ex W. C. Holmes resultou na identificação de 16 substâncias: os esteróides: campesterol, estigmasterol e $\beta$-sitosterol; os diterpenos: ácido ent-15ß-E-cinamoiloxi-caur-16-en19-óico, ácido ent-15ß-Z-cinamoiloxi-caur-16-en-19óico e ácido ent-caur-16-en-19-óico; os triterpenos: $\alpha$-amirina, $\beta$-amirina, acetato de $\alpha$-amirina, acetato de $\beta$-amirina, lupeol, acetato de lupeol e friedelina; a cumarina: escopoletina; o flavonóide: quercetina e o derivado do ácido cafeoilquínico: 4,5-di-O-[E]cafeoilquínico.

UNITERMOS: Mikania pseudohoffmanianna. Asteraceae. Terpenóides. Flavonóide. Derivado do ácido quínico.

\section{REFERENCES}

ALVES, T. M. A.; CHAVES, P. P. G.; SANTOS, L. M. S. T.; NAGEM, T. J.; MURTA, S. M. F.; CERAVOLO, I. P.; ROMANHA, A. J.; ZANI, C. L. A. Diterpene from Mikania obtusata active on Trypanosoma cruzi. Planta Med., v.61, n.1, p.85-87, 1995.

DEAN, F. M. The coumarins of Ptaeroxylon obliquun. Tetr. Lett., v.23, p.2147-2151, 1967.

ERLEND, H.; DAG, E. Study of collision-induced radical cleavage of flavanoid glycosides using negative electrometry ionization tandem quadrupole mass spectrometry. J. Mass Spectrom., v.38, p.43-49, 2002.

FABRE, N.; RUSTAN, N.; HOFFMANN, D. E.; QUETINLECLERCQ, J. Determination of flavone, flavonol and flavanone aglycones by negative ion liquid chromatography electrospray ion trap mass. spectrometry. J. Am. Soc. Mass Spectrom., v.12, p.707-715, 2001.

HARBORNE, J. B.; GRAYER, R. J. Flavonoids and insects. In: HARBORNE, J. B., (Ed.) The flavonoids - advances in research since. 1986. London; Chapman and Hall, 1993. Cap.14, p.589-618.

HOLETZ, F. B.; PESSINI, G. L.; SANCHES, N. R.; CORTEZ, D. A. G.; NAKAMURA, C. V.; DIAS FILHO, B. P. Screening of some plants used in the Brazilian folk medicine for the treatment of infectious diseases. Mem. Inst. Oswaldo Cruz., v. 97, n.7, p.1027-1031, 2002.

KING, R. M.; ROBISON, H. The Genera of the Eupatorieae (Asteraceae), Monographys in Systematic Botany, The Missouri Botanical Garden; KING, R. M.; ROBINSON, H., Eds.; Allen Press, Inc.; Lawrence, Kansas, 1987, v.22, p.416.

LENTZ, L. L.; CLARK, M. A.; HUFFORD, D. C.; MEURER-GRIMES, B.; PASSEREITER,M. C.; CORDERO, J.; IBRAHIMI, O.; OKUNADE L. A. Antimicrobial properties of Honduran medicinal plants. $J$. Ethnopharmacol., v.63, p.253-263, 1998. 
MERFORT, I. Caffeoylquinic acids from flowers of Arnica montana and Arnica chamissonis. Phytochemistry, v.31,n.6, p.2111-2113, 1992.

MOURA, DE. S. R.; COSTA, J. M. J.; SILVA, A. C.; LOPES, S. C.; BERNARDO-FILHO, M.; SILVA DA NASCIMENTO, V.; PORTELA, N. B.; RUBENICH, S. M. L.; CARVALHO, M. R. C. L. Bronchodilatador activity of Mikania glomerata Sprengel on human bronchi and guinea-pig trachea. J. Pharm. Pharmacol., v.54, p.249-256, 2001.

NASCIMENTO, A. M.; OLIVEIRA, D. C. R. Kaurrene diterpenes and other chemical constituentes from Mikania stipulacea (M. Vahl) Willd. J. Braz. Chem. Soc., v.12, n.4, p.552-555, 2001.

OHNO, N.; MABRY, T. J.; ZABEL, V.; WATSON, W. H. Tetrachyrin, a new rearranged kaurenoid, lactone and diterpenes Helianthos-debilis and acids from Tetrachyron-orizaboensis. Phytochemistry, v.18, n.10, p.1687-1689, 1979.

PAULI, G. F.; POETSCH, F.; NAHRSTEDT, A. Struture assignment of natural quinic acid derivatives using proton nuclear magnetic resonance techniques. Phytochem. Anal., v.9, p.177-185, 1998

REED, G. A.; DIMMEL, R. D.; MALCOLM, E. W. Influence of nucleophiles on the high temperature aqueous isomerization of cis- to trans- cinamic acid. $J$. Org. Chem., v.58, n.23, p.6364-6371, 1993.
SÁNCHEZ-RABANEDA， F.; JÁUREGUI， O.; LAMUELA-RAVENTÓS, R. M.; BATISTA, J.; VILA DO MAT, F.; CODINA, C., Identification of phenolic compounds in artichoke waste by high-performance liquid chromatography-tandem mass espectrometry. $J$. Chromatogr. A, v.1008, p.57-72, 2003.

SANTOS, P. A. Estudos químicos de espécies de "arnicas de serra brasileira" (tribo Vernonieae, Asteraceae). Ribeirão Preto, 2004. 144 p. Tese de Doutorado Faculdade de Ciências Farmacêutica de Ribeirão Preto, Universidade de São Paulo.

SILVERSTEIN, R. M.; BASSLER, G. C.; MORRILL, T. C. Identificação espectrométrica de compostos orgânicos. 5 ed. Rio de Janeiro: Editora Guanabara Koogan, 1994 p.299.

VELANDIA, J. R.; DE CARVALHO, M. G.; BRAZFILHO, R. Ácido ent-16a, 17-diidroxicauran-19-óico isolado de Ouratea semiserrata e os desafios estereoquímicos dos carbonos quinais C-4 e C-16. Quím. Nova, v.21, n.4, p.397-404, 1998.

VICHNEWSKI, W.; LEITÃO FILHO, H. F.; MURARI, R.; HERZ, W. Cinnamoylgrandifloric acid from Mikania oblongifolia. Phytochemistry, v.16, n.12, p.2028-2029, 1977.

YAMASAKI, K.; KOHDA, H.; KOBAYASHI, T.; KASAI, R.; TANAKA, O. Strutures of Stevia diterpeneglucosides-application of C-13 NMR Tetr. Lett., v.13, p.1005-1008, 1976.

Recebido para publicação em 30 de março de 2005. Aceito para publicação em 12 de agosto de 2005. 